\title{
PCR methods and plasmid profile analysis for characterisation of Histophilus ovis strains
}

\author{
S. APPUHAMY, J. C. LOW*, J. G. COOTE and R. PARTON \\ Division of Infection and Immunity, University of Glasgow G12 800 and * Scottish Agricultural College \\ Veterinary Science Division, Bush Estate, Penicuik EH26 OQE
}

\begin{abstract}
The value of polymerase chain reaction (PCR)-based DNA fingerprinting and plasmid profile analysis for differentiation of Histophilus ovis isolates was assessed. Nineteen isolates of $\boldsymbol{H}$. ovis were typed by PCR-ribotyping, repetitive extragenic palindromic element (REP)-PCR and enterobacterial repetitive intergenic consensus (ERIC)-PCR. These methods distinguished five types by PCR-ribotyping, 11 types by REP-PCR and seven types by ERIC-PCR. The ribotyping method produced a relatively simple pattern and a small number of distinct types and was useful for differentiation of $\boldsymbol{H}$. ovis from the phenotypically similar organism, Haemophilus somnus. REP- and ERIC-PCR both produced complex banding patterns, but increased the discrimination between strains. Plasmids were found in 12 of the 19 isolates and there were four different plasmid profiles. A combination of the PCR methods and plasmid profile analysis provided a high resolution typing method for $H$. ovis.
\end{abstract}

\section{Introduction}

The name Histophilus ovis has been applied to gramnegative pleomorphic coccobacilli isolated from sheep with a variety of conditions including mastitis, septicaemia, pyaemia, polyarthritis, metritis, abortion and most frequently epididymitis [1-3]. Its presumptive identification is generally dependent on cultural and biochemical methods [4], but these give variable results [5]. The taxonomic status of $H$. ovis is unclear, but it resembles Haemophilus somnus, an organism that causes similar diseases in cattle, in its cultural, biochemical and antigenic properties. Stephens et al. [6] suggested that these bacteria and an organism referred to as Haem. agni should be considered as a single Haemophilus-Histophilus group and they pointed out the problem of differentiation of strains within the group. Confusingly, there has been a trend to identify both bovine and ovine isolates of these organisms in North America as Haem. sommus [7] and in Australia as $H$. ovis [6,8]. DNA-DNA hybridisation studies have shown that Haem. somnus and $H$. ovis are genetically homogeneous [9], but others have suggested, on the basis of restriction endonuclease analysis, biotyping and outer-membrane

Received 29 Nov. 1997; revised version received 5 March 1998; accepted 11 March 1998.

Corresponding author: Dr R. Parton. protein profiles $[7,10]$, that bovine and ovine isolates should be considered as separate groups.

Polymerase chain reaction (PCR)-based fingerprinting methods have been applied recently to several bacterial genera as an aid to strain differentiation [11]. Some of these methods use primers for specific target sequences such as repetitive extragenic palindromic (REP) elements and enterobacterial repetitive intergenic consensus (ERIC) sequences which are dispersed throughout the genome in many bacterial species $[12,13]$. Versalovic et al. [14] defined primers targeting these REP and ERIC sequences for the study of eubacterial species and revealed that inter-REP or inter-ERIC distances and patterns are specific for bacterial species and for strains within a species. PCRribotyping is another method that has been used to explore the bacterial genome and the rRNA genetic loci are frequently present in multiple copies. The genes within the rRNA loci are separated by spacer regions that exhibit a large degree of sequence and length variation at the level of genus and species. This diversity is due in part to variations in the number and type of tRNA sequences found within the spacers [15].

In previous studies, a combination of PCR-ribotyping, REP-PCR and ERIC-PCR techniques was used for identification and fingerprinting of Haem. somnus isolates of bovine origin [16] and Actinobacillus 
seminis isolates of ovine and bovine origin [17]. These methods were also found to be applicable to the characterisation of $H$. ovis strains. Subgroups of $H$. ovis isolates of ovine origin have been identified by the presence of plasmids of different sizes [5], and so the utility of plasmid profiles in the differentiation of $H$. ovis strains was also examined.

\section{Materials and methods}

\section{Bacterial isolates}

For the purposes of this study, isolates from cattle and sheep, showing similar cultural and biochemical properties to those described by Humphrey and Stephens [1], are referred to as Haem. somnus and $H$. ovis respectively. Nineteen strains of $H$. ovis isolated by the Scottish Agricultural College Veterinary Science Division were available (Table 1). The first UK isolate - of Low and Graham [2], designated as SA24 - was used as a reference strain, as there is no type strain available in any of the major culture collections. Isolates were stored at $-80^{\circ} \mathrm{C}$ in Brain Heart Infusion (BHI) Broth (Oxoid) supplemented with glycerol 10\% $\mathrm{v} / \mathrm{v}$, Tris $(\mathrm{BDH}) 1 \% \mathrm{w} / \mathrm{v}$, soluble starch $(\mathrm{BDH}) 1 \%$ $\mathrm{w} / \mathrm{v}$, sodium-L-aspartate (Sigma) $0.5 \% \mathrm{w} / \mathrm{v}$ and thiamine monophosphate (Sigma) $0.001 \% \mathrm{w} / \mathrm{v}, \mathrm{pH}$ 7.8 [16]. They were propagated on BHI Agar (Oxoid) containing sheep blood $5 \% \mathrm{v} / \mathrm{v}$ and yeast extract (Oxoid) $0.5 \% \mathrm{w} / \mathrm{v}$ (BHIBYE) and plates were incubated at $37^{\circ} \mathrm{C}$ for $48 \mathrm{~h}$ in a candle jar. Their identity as $H$. ovis was confirmed by a panel of cultural and biochemical tests [6] and by the API ZYM system (bioMerieux, Marcy l'Etoile, France) [18].
PCR

The supernates from standardised bacterial suspensions which had been boiled then centrifuged served as the source of template DNA for PCR, as described previously [16]. Primers, optimised PCR conditions and electrophoresis of amplified products were also as described previously $[16,17]$. The amplimers were photographed under UV illumination. Photographs were inspected visually and different band profiles were given a number or letter whenever a distinct pattern was observed. The reproducibility of the band patterns was assessed not only by repeat PCR experiments with the same template sample, but also with template samples derived from different cultures. Good reproducibility of PCR amplification products was obtained, although some minor, day-to-day variation in intensity was observed with the less intense amplimers.

\section{Plasmid DNA extraction}

Plasmid preparations were done with a QIAprep Spin Plasmid Kit (QIAGEN, West Sussex) according to the manufacturer's instructions. Plasmid DNA $(10-15 \mu 1)$ was analysed by electrophoresis in agarose type II-A (Sigma) $0.8 \% \mathrm{w} / \mathrm{v}$ in Tris-borate-EDTA buffer $(0.045 \mathrm{M}$ Tris-borate, $0.001 \mathrm{M}$ EDTA, $\mathrm{pH} 8.0$ ) containing ethidium bromide $0.5 \mu \mathrm{g} / \mathrm{ml}$.

\section{Results and discussion}

PCR-ribotyping of the $H$. ovis isolates produced simple banding patterns as shown in Fig. 1 and five distinct fingerprints were recognised for the 19 isolates, as

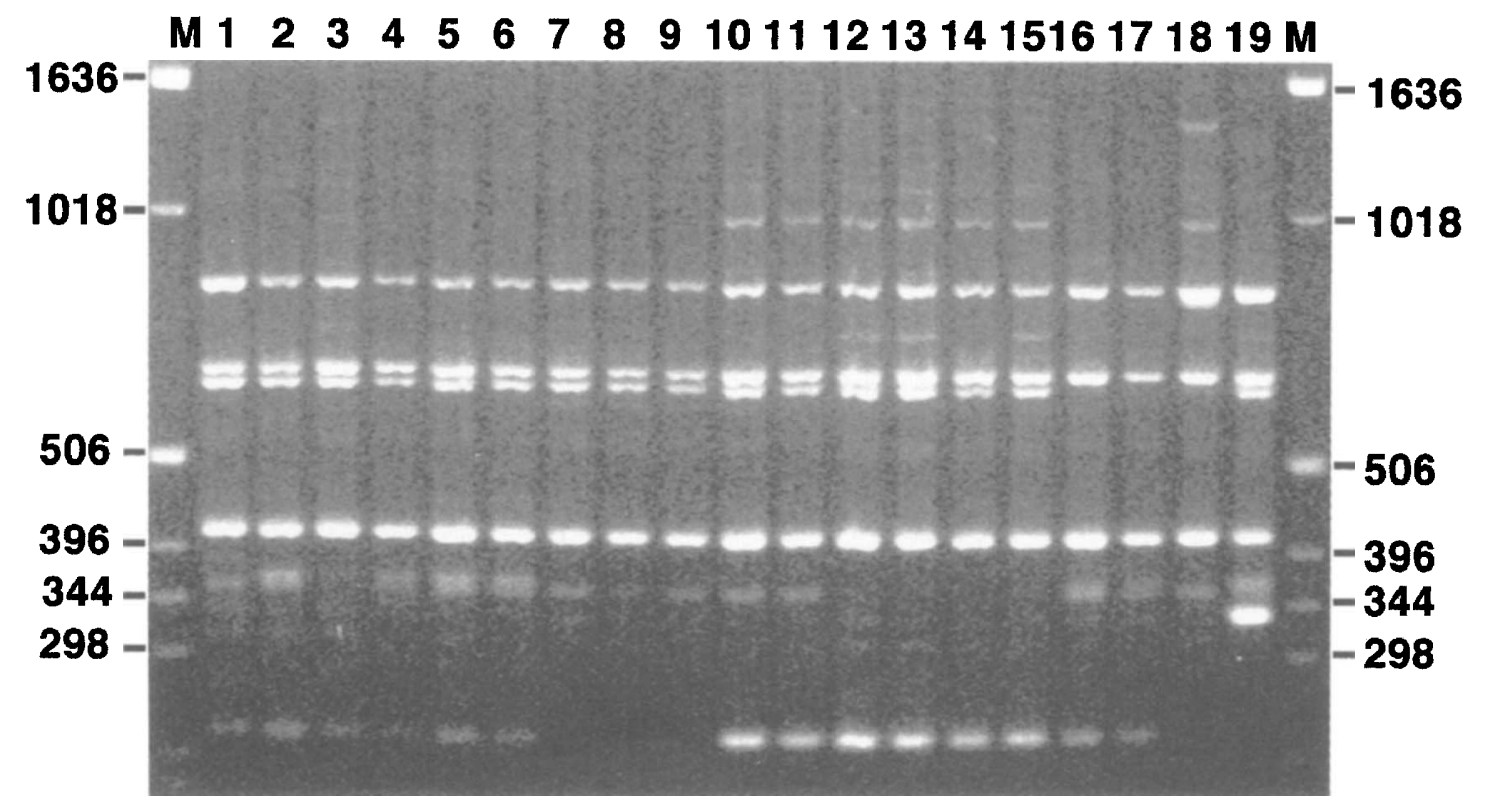

Fig. 1. Fingerprints obtained by PCR-ribotyping for $H$. ovis isolates. Lanes M, 1-kb DNA ladder. Lanes 1-19, H. ovis isolates, SA8, SA26, SA16, SA73, SA45, SA46, SA56, SA57, SA58, SA55, SA26, SA27, SA28, SA44, SA54, SA69, SA72, SA53 and SA24 respectively. The profiles have been arranged so that isolates of a similar type are grouped together. Lanes 1-6 (type a), lanes 7-9 (type c), lanes 10-15 (type b), lanes 16-18 (type d) and lane 19 (type e) (see Table 1). 
noted in Table 1. The bands ranged from 215 to $>1018$ bp with three markers, of 400,700 and $900 \mathrm{bp}$, common to all $H$. ovis isolates. The variation in patterns of amplimers generated by PCR-ribotyping indicated some diversity in number and structure of the ribosomal operons in $H$. ovis and such polymorphisms have been reported for other bacterial species [19].
The PCR-ribotyping patterns for the $H$. ovis isolates were similar to those of Haem. somnus as shown in Fig. 2 and as reported previously [16]. Nevertheless, the majority of the $H$. ovis isolates could be readily differentiated from Haem. somnus isolates by the presence of a dual band in the $H$. ovis isolates at $c$. 700 bp (arrow, Fig. 2). However, three H. ovis isolates (SA53, SA69 and SA72, lanes 16-18 in Fig. 1) from

Table 1. Distribution of $H$. ovis isolates among PCR and plasmid types

\begin{tabular}{|c|c|c|c|c|c|c|c|}
\hline $\begin{array}{l}\text { Isolate } \\
\text { no. }\end{array}$ & $\begin{array}{l}\text { Ovine } \\
\text { source }\end{array}$ & $\begin{array}{l}\text { Host } \\
\text { status }\end{array}$ & $\begin{array}{l}\text { Geographic } \\
\text { origin }\end{array}$ & $\begin{array}{l}\text { REP } \\
\text { type }\end{array}$ & $\begin{array}{l}\text { ERIC } \\
\text { type }\end{array}$ & Ribotype & $\begin{array}{c}\text { Plasmid } \\
\text { type }\end{array}$ \\
\hline SA29 & Semen & Fertile & No record & 1 & A & $\mathrm{a}$ & $\beta$ \\
\hline SA45 & Semen & No record & Southern Scotland & 1 & A & $\mathrm{a}$ & $\beta$ \\
\hline SA46 & Semen & Fertile & Central Scotland & 1 & $\mathrm{~A}$ & $\mathrm{a}$ & $\beta$ \\
\hline SA73 & Semen & No record & Northern England & 1 & A & $\mathrm{a}$ & $\delta$ \\
\hline SA16 & Semen & No record & No record & 2 & $\mathrm{~B}$ & $\mathrm{a}$ & $\alpha$ \\
\hline SA27 & Semen & Subfertile & Northern England & 2 & $\mathrm{~B}$ & $\mathrm{~b}$ & $\alpha$ \\
\hline SA44 & Semen & Fertile & No record & 2 & $\mathrm{~B}$ & $\mathrm{~b}$ & $\alpha$ \\
\hline SA $56^{*}$ & Vagina & Subfertile & Central Scotland & 3 & $\mathrm{C}$ & $\mathrm{c}$ & $\varepsilon$ \\
\hline SA $57^{*}$ & Vagina & Subfertile & Central Scotland & 3 & $\mathrm{C}$ & $\mathrm{c}$ & $\varepsilon$ \\
\hline SA $58^{*}$ & Vagina & Subfertile & Central Scotland & 3 & $\mathrm{C}$ & $\mathrm{c}$ & $\varepsilon$ \\
\hline SA26 & Semen & Fertile & Central Scotland & 4 & $\mathrm{~B}$ & $b$ & $\alpha$ \\
\hline SA55 & Semen & Infertile & Northern Scotland & 4 & B & $b$ & $\alpha$ \\
\hline SA28 & Semen & Subfertile & Northern England & 5 & $\mathrm{~B}$ & $b$ & $\alpha$ \\
\hline SA54 & Semen & Subfertile & Central Scotland & 6 & $\mathrm{~B}$ & $\mathrm{~b}$ & $\alpha$ \\
\hline SA69 & Semen & Fertile & Southern Scotland & 7 & $\mathrm{D}$ & d & $\varepsilon$ \\
\hline SA 72 & Prepuce & Fertile & Central Scotland & 8 & $\mathrm{D}$ & $\mathrm{d}$ & $\gamma$ \\
\hline SA53 & Semen & Infertile & Central Scotland & 9 & $\mathrm{E}$ & $\mathrm{d}$ & $\varepsilon$ \\
\hline $\mathrm{SA} 24^{\dagger}$ & Semen & Infertile & Southern Scotland & 10 & $\mathrm{~F}$ & $\mathrm{e}$ & $\varepsilon$ \\
\hline SA08 & Semen & No record & No record & 11 & $\mathrm{G}$ & $\mathrm{a}$ & $\varepsilon$ \\
\hline
\end{tabular}

${ }^{*}$ Isolated from different animals of the same flock that showed subnormal fertility.

${ }^{\dagger} \mathrm{SA} 24$ : reference isolate [3].

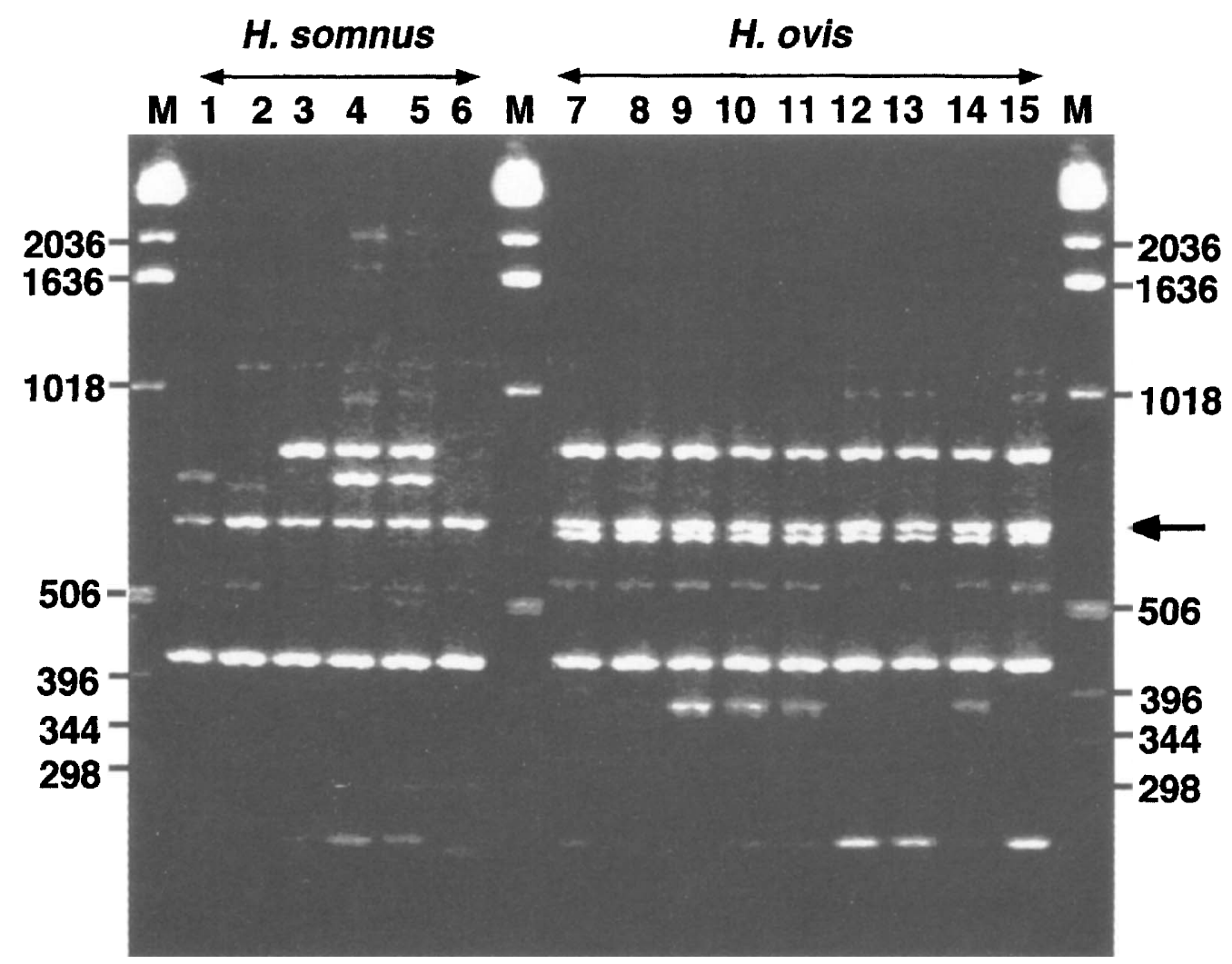

Fig. 2. Differentiation of Haem. somnus and $H$. ovis by PCR-ribotyping. Lanes M, 1-kb DNA ladder. Lanes 1-6, different representative ribotypes of Haem. somnus isolates; 7-15, H. ovis isolates SA08, SA16, SA24, SA46, SA45, SA26, SA27, SA29 and SA44 respectively. The arrow indicates the main band difference between Haem. somnus and these $H$. ovis isolates. 
different ovine sources did not show this dual band, but had ribotyping patterns very similar to those obtained with several strains of Haem. somnus of bovine origin (Fig. 3, lanes 1-6). Thus the hostspecific relationship suggested for these organisms may not be absolute. The bovine and ovine strains showed similar but distinct banding patterns by REPand ERIC-PCR (Fig. 3). Two of the ovine isolates (SA69 and SA72) showed similar profiles by ERICPCR (Fig. 3, lanes 17 and 18), but they had unique profiles by REP-PCR (Fig. 3, lanes 11 and 12).

REP-PCR produced 11 distinguishable patterns for the $19 \mathrm{H}$. ovis isolates and, therefore, the highest degree of discrimination between isolates (Table 1). The banding patterns were more complex than those seen with the ERIC-PCR and PCR-ribotyping methods, with bands ranging in size from 250 to $2500 \mathrm{bp}$ and of various intensities. There were REP markers of 350 , $400,475,520,750,950$ and $1000 \mathrm{bp}$ common to all $H$. ovis isolates. With ERIC-PCR, seven distinct patterns were seen, as indicated in Table 1. The amplified bands ranged from 75 to $950 \mathrm{bp}$ with bands common to all isolates at 154 and $750 \mathrm{bp}$. Examples of REP-PCR and ERIC-PCR fingerprints for $H$. ovis and Haem. somnus isolates are shown in Fig. 3.
Twelve $(63 \%)$ of the $19 \mathrm{H}$. ovis isolates showed the presence of plasmids. Seven isolates contained two plasmids, of 3.7 and $5.0 \mathrm{~kb}$ (Fig. 4, lanes 1-4, 6, 9, 10 ), and this profile was designated as type $\alpha$ (Table 1). Three isolates contained one plasmid of $2.9 \mathrm{~kb}$ (lanes $5,7,8$, profile type $\beta$ ). One isolate contained two plasmids, of 2.3 and $2.9 \mathrm{~kb}$ (lane 11 , type $\gamma$ ) and one contained plasmids of 2.5 and $3.0 \mathrm{~kb}$ (lane 12 , type $\delta$ ). The profile of those strains without plasmids was designated as type $\varepsilon$. There was some evidence for the presence of larger plasmids in certain strains, e.g., strains SA16 and SA72 (Fig. 4, lanes 1 and 11) but the procedure used for plasmid isolation was not ideal for larger plasmids and other procedures were not investigated. In general, plasmids of these $H$. ovis isolates were of low copy number when compared with plasmid pUC19 from Escherichia coli (Fig. 3, lane E). There were no obvious differences between these isolates in their antibiotic resistance profiles (tested by the disk diffusion method against a range of antibiotics commonly used for treatment of $\mathrm{H}$. ovis infections) that could be related to the presence of a particular plasmid (data not shown). In another study, all $H$. ovis isolates tested, but none of the Haem. somnus isolates, contained plasmids [5] and the method was used to differentiate $H$. ovis from Haem.

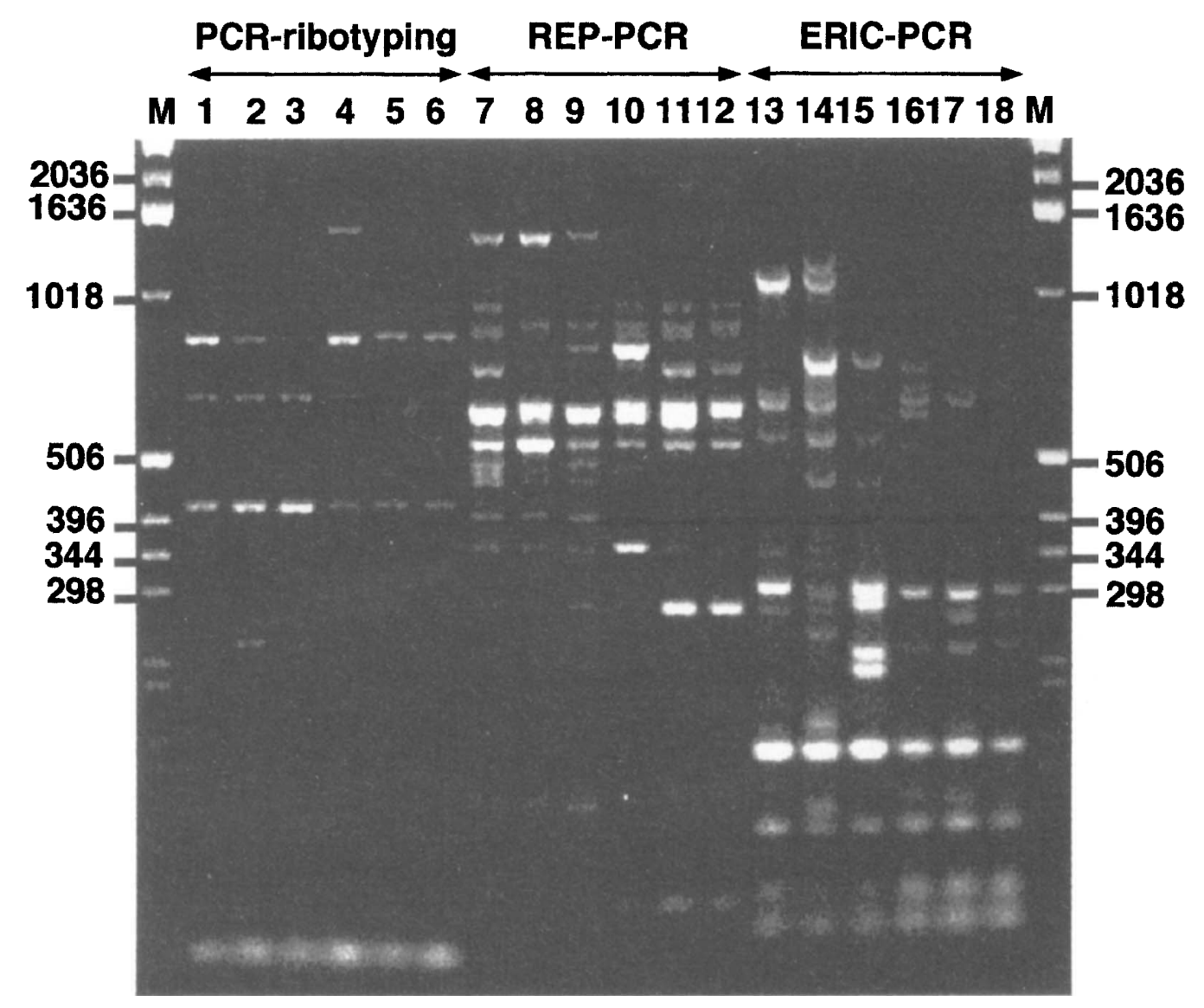

Fig. 3. Comparison of the profiles of three ovine isolates $(H$. ovis, lanes 4-6, 10-12, 16-18) with those of three bovine isolates (Haem. somnus, lanes 1-3, 7-9, 13-15) by the three PCR fingerprinting methods. Lanes M, 1-kb DNA ladder. Lanes 1-6, PCR-ribotyping; 7-12, REP-PCR; 13-18, ERIC-PCR. Haem. somnus: strains SA12 (lanes 1, 7, 13); V3 $(\mathbf{2}, \mathbf{8}, \mathbf{1 4})$; X4 (3, 9, 15). H. ovis: strains SA53 (lanes 4, 10, 16); SA69 (5, 11, 17); SA72 (6, 12, 18). 


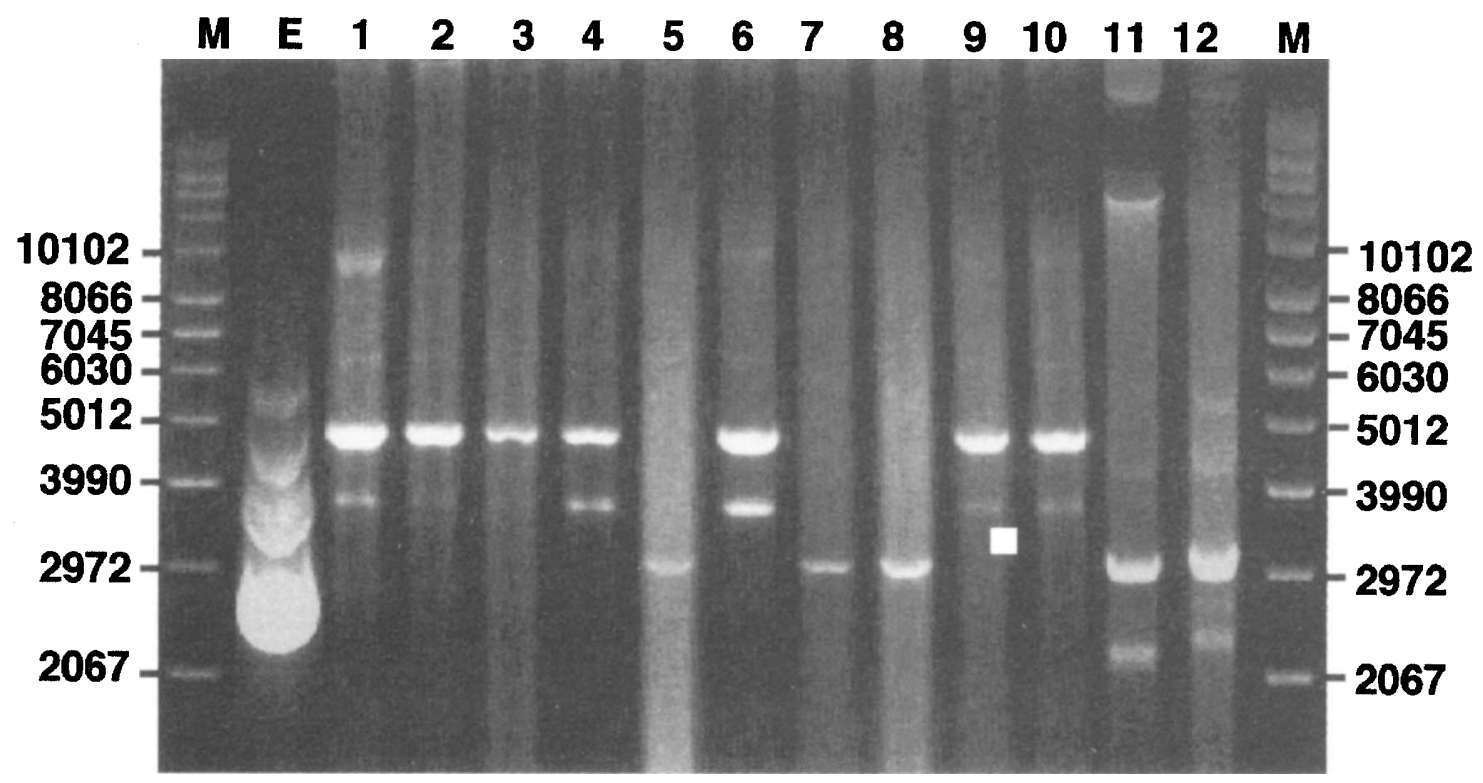

Fig. 4. Plasmid profiles of $H$. ovis isolates. Lanes M, supercoiled DNA ladder (GibcoBRL, Paisley); E, E. coli pUC19. Lanes 1-12, SA16, SA26, SA27, SA28, SA29, SA44, SA45, SA46, SA54, SA55, SA72 and SA73 respectively.

somnus. In contrast, Fussing and Wegener [20] found that $20 \%$ of Danish Haem. somnus isolates contained plasmids. In a parallel study to that reported here, four (13\%) of 29 Haem. somnus contained single plasmids and their size ranged from 1.5 to $3.5 \mathrm{~kb}$ [21]. None of these plasmids was similar to those of the $H$. ovis isolates and the three $H$. ovis isolates that were similar to Haem. somnus by PCR-ribotyping did not have plasmids.

The first reported isolate of $H$. ovis in the UK, used as a reference strain for $H$. ovis in this study (SA24), appeared to be unique (Table 1) and, therefore, was perhaps not the best choice as reference. Three isolates (SA56, SA57 and SA58) from different animals of the same flock with subnormal fertility were indistinguishable by all four typing methods, suggesting the dissemination of a single virulent strain within the flock. Other isolates from different geographic locations also had identical fingerprints (e.g., SA45 and SA46, SA26 and SA55). These relationships among $H$. ovis isolates revealed by the typing methods indicated that there may be only a limited number of distinct strains in sheep flocks in Scotland and Northern England, although investigation of a larger number of isolates would be necessary to confirm this suggestion. Also, if isolates from different disease syndromes had been examined, as for Haem. somnus [16], a greater diversity of types might have been demonstrated.

Previously, PCR as a means of fingerprinting of $H$. ovis isolates had been applied only with random primers [22]. A single isolate of $H$. ovis was compared with a number of isolates of Haem. somnus and was clearly distinct. In the present study, PCRribotyping clearly differentiated all except three of the
H. ovis isolates from Haem. somnus. The relationship between these three sheep strains (H. ovis) and Haem. somnus requires further investigation, perhaps by $16 \mathrm{~S}$ rRNA sequences analysis. REP-PCR produced the highest discrimination between $H$. ovis strains, whereas with Haem. somnus the highest discrimination was obtained with ERIC-PCR [16].

In conclusion, a combination of all three PCR primer sets provided a potentially useful typing system for $H$. ovis. Plasmid profile analysis added a further level of discrimination and was a useful supplement to the PCR typing methods.

S. A. was supported by an Agricultural Research Scholarship from the Government of Sri Lanka and a scholarship provided by the Institute of Biomedical and Life Sciences, University of Glasgow. The useful comments of Dr D. J. Taylor, Department of Veterinary Pathology, University of Glasgow and the kind co-operation of Mr M. J. A. Mylne, Veterinary Officer In Charge, Edinburgh Genetics, Bush Estate, Penicuik, Scotland, are gratefully acknowledged.

\section{References}

1. Roberts DS. A new pathogen from ewe with mastitis. Aust Vet $J$ 1956; 32: 330-332.

2. Low JC, Graham MM. Histophilus ovis epididymitis in a ram in the UK. Vet Rec 1985; 117: 64-65.

3. Humphrey JD, Stephens LR. 'Haemophilus somnus': a review. Vet Bull 1983; 53: 987-1004.

4. Webb RF. Bacteriological characteristics of Histophilus ovis and its relationship to similar bacteria. Res Vet 1983; 35: $25-29$.

5. Kirkham C, Biberstein EL, LeFebvre RB. Evidence of hostspecific subgroups among 'Histophilus ovis' isolates. Int J Syst Bacteriol 1989; 39: 236-239.

6. Stephens LR, Humphrey JD, Little PB, Barnum DA. Morphological, biochemical, antigenic, and cytochemical relationships among Haemophilus somnus, Haemophilus agni, Haemophilus haemoglobinophilus, Histophilus ovis, and Actinobacillus seminis. J Clin Microbiol 1983; 17: 728-737.

7. Ward ACS, Jaworski MD, Eddow JM, Corbeil LB. 
A comparative study of bovine and ovine Haemophilus somnus isolates. Can J Vet Res 1995; 59: 173-178.

8. McGillivery DJ, Webber JJ, Dean HF. Characterisation of Histophilus ovis and related organisms by restriction endonuclease analysis. Aust Vet $J$ 1986; 63: 389-393.

9. Piechulla K, Mutters R, Burbach S, Klussmeier R, Pohl S, Mannheim W. Deoxyribonucleic acid relationships of 'Histophilus ovis/Haemophilus somnus', Haemophilus haemoglobinophilus, and 'Actinobacillus seminis'. Int J Syst Bacteriol 1986; 36: $1-7$.

10. Walker RL, Biberstein EL, Pritchett RF, Kirkham C. Deoxyribonucleic acid relatedness among 'Haemophilus somnus', 'Haemophilus agni', 'Histophilus ovis', 'Actinobacillus seminis', and Haemophilus influenzae. Int J Syst Bacteriol 1985; 35: 46-49.

11. Kerr KG. The rap on REP-PCR-based typing systems. Rev Med Microbiol 1994; 5: 233-244.

12. Lupski JR, Weinstock GM. Short, interspersed repetitive DNA sequences in prokaryotic genomes. $J$ Bacteriol 1992; 174: 4525-4529.

13. Sharples GJ, Lloyd RG. A novel repeated DNA sequence located in the intergenic regions of bacterial chromosomes. Nucleic Acids Res 1990; 18: 6503-6508.

14. Versalovic J, Koeuth T, Lupski JR. Distribution of repetitive DNA sequences in eubacteria and application to fingerprinting of bacterial genomes. Nucleic Acids Res 1991; 19: 6823-6831.

15. Jensen MA, Webster JA, Straus N. Rapid identification of bacteria on the basis of polymerase chain-reaction amplified ribosomal DNA spacer polymorphisms. Appl Environ Microbiol 1993; 59: 945-952.

16. Appuhamy S, Parton R, Coote JG, Gibbs HA. Genomic fingerprinting of Haemophilus somnus by a combination of PCR methods. J Clin Microbiol 1997; 35: 288-291.

17. Appuhamy S, Coote JG, Low JC, Parton R. PCR methods for rapid identification and characterization of Actinobacillus seminis strains. J Clin Microbiol 1998; 36: 814-817.

18. Cousins DV, Lloyd JM. Rapid identification of Haemophilus somnus. Histophilus ovis and Actinobacillus seminis using the API ZYM system. Vet Microbiol 1988; 17: 75-81.

19. Gürtler V, Stanisich VA. New approaches to typing and identification of bacteria using the 16S-23S rDNA spacer region. Microbiology 1996; 142: 3-16.

20. Fussing V, Wegener HC. Characterization of bovine Haemophilus somnus by biotyping, plasmid profiling, REA-patterns and ribotyping. Int $J$ Med Microbiol Virol Parasitol Infect Dis 1993; 279: 60-74

21. Appuhamy S. DNA fingerprinting of Haemophilus somnus, Histophilus ovis and Actinobacillus seminis. $\mathrm{PhD}$ thesis, University of Glasgow, 1997.

22. Myers LE, Silva SVPS, Procunier JD, Little PB. Genomic fingerprinting of 'Haemophilus somnus' isolates by using a random-amplified polymorphic DNA assay. $J$ Clin Microbiol 1993; 31: $512-517$. 